\title{
Terpolymerization of Styrene, Norbornene, and Carbon Monoxide with a Palladium Catalyst
}

\author{
Der-Jang Liaw, * Jang-Shiang TsaI, and Biing-Ferng LAY \\ Department of Chemical Engineering, National Taiwan Institute of Technology, \\ Taipei, Taiwan 106, Republic of China \\ (Received January 4, 1996)
}

\begin{abstract}
In this work, the authors conducted the terpolymerization of carbon monoxide (CO), styrene (St), and norbornene (NBE) with $\mathrm{Pd}\left(\mathrm{CH}_{3} \mathrm{COO}\right)_{2}$ in $\mathrm{CH}_{3} \mathrm{OH}$ under various molar ratios of norbornene to styrene at $90^{\circ} \mathrm{C}$. Infrared spectra, ${ }^{1} \mathrm{H}$ NMR and ${ }^{13} \mathrm{C}$ NMR analyses confirmed that the NBE/St/CO terpolymers contain ketone, styrene unit, and ring structure of norbornene. Physical and thermal properties of the NBE/St/CO terpolymers were also investigated by a differential scanning calorimeter (DSC), thermogravimetric analysis (TGA), solubility and X-ray diffraction analyses. The results indicated that glass transition temperature $\left(T_{\mathrm{g}}\right)$ of the terpolymers increased when norbornene was introduced. Terpolymer increased molar ratio of norbornene to styrene was found to not only be more thermally stable, but also to increase solubility. As the NBE/St molar ratio became larger than 0.375 in terpolymer, the terpolymers were soluble in chloroform, tetrahydrofuran (THF), methylene chloride, ethyl acetate, benzene, dimethylacetamide (DMAc), and pyridine. X-ray diffraction results indicated that the terpolymer increased molar ratio of $\mathrm{NBE} / \mathrm{St}$ in the terpolymer decreased the degree of crystallinity and the angle of maximum intensity owing to the bulky norbornene group. Hydrogenation of NBE/St/CO terpolymer with a reducing agent yielded a hydroxyl-containing polymer.

KEY WORDS Terpolymer/Polyketone/Carbon Monoxide/ Norbornene / Styrene / Palladium Catalyst /
\end{abstract}

The polymerization of carbon monoxide $(\mathrm{CO})$ and olefins is of increasing interest for the following reasons. ${ }^{1}$ First, carbon monoxide is relatively inexpensive. Second, polymers containing polyketones have the potential to become photodegradable or biodegradable polymers in a new class. ${ }^{2-4}$ Third, because the carbonyl group can be easily modified chemically, polyketones are expected to be excellent starting materials in synthesizing functional polymers of a new type. ${ }^{5,6}$

Although thoroughly discussing the terpolymerization of carbon monoxide, ethylene, and propylene, previous investigators have obtained only a few experimental results. ${ }^{8-10}$ Furthermore, the blending of the ethylene/ propylene/CO terpolymer with other polymers (acrylonitrile-butadiene-styrene (ABS), polyarylsulfone) $)^{11,12}$ which subsequently enhance modulus and melt strength have also been studied. Although the terpolymerization of $\mathrm{CO}$, styrene $(\mathrm{St})$, with various olefins such as ethylene and propylene using palladium catalyst is patented, ${ }^{13-15}$ terpolymer involving $\mathrm{CO}$, styrene, and norbornene (NBE) has received only slight attention. Other workers contend that the polymer containing norbornene groups has a thermoplastic nature. ${ }^{16,17}$ Other properties (e.g., glass fiber reinforcement, flame retardency and impact toughness) have also been recognized. ${ }^{16,17}$ Thus, an approach to produce the new NBE/St/CO terpolymer having good thermal properties is of interest. Furthermore, the NBE/St/CO terpolymer can be hydrogenated to yield the hydroxyl-containing polymer which reacts with curing agents to obtain thermoset resins. ${ }^{18}$

This study presents results on the terpolymerization of $\mathrm{CO}$, styrene and norbornene in the presence of $\mathrm{Pd}\left(\mathrm{CH}_{3} \mathrm{COO}\right)_{2}$ at $90^{\circ} \mathrm{C}$. Measurements of IR spectra, ${ }^{1} \mathrm{H}$ NMR and ${ }^{13} \mathrm{C}$ NMR are also taken and analyzed. The influence of norbornene content in NBE/St/CO ter-

\footnotetext{
* To whom correspondence should be addressed.
}

polymers on yield, molecular weight, thermal properties, solubility, and crystallinity are studied. Finally, the hydrogenation of the NBE/St/CO terpolymer with the reducing agent (lithium aluminum hydride, $\mathrm{LiAlH}_{4}$ ) in tetrahydrofuran (THF) is also discussed.

\section{EXPERIMENTAL}

\section{Materials}

Carbon monoxide (99.3\% purity) was purchased (Air Products and Chemicals Inc.). Norbornene (Merck) was distilled twice from calcium hydride under dry nitrogen (purity $>99 \%$ by GC). Styrene (Merck) was dried over $\mathrm{CaH}_{2}$, distilled and stored under dry nitrogen in a refrigerator before used. Catalyst $\mathrm{Pd}\left(\mathrm{CH}_{3} \mathrm{COO}\right)_{2}$ and oxidant (1,4-naphthoquinone) were purchased from Merck, Germany. Ligand 2,2'-bipyridine (Merck) and $p$-toluenesulfonic acid (TCI) were used directly without purification. Solvents were purified according to standard methods.

\section{Terpolymerization of Norbornene, Styrene, and Carbon Monoxide}

To a solution containing $\mathrm{Pd}\left(\mathrm{CH}_{3} \mathrm{COO}\right)_{2}(0.022 \mathrm{~g}$, $0.1 \mathrm{mmol}), 2,2^{\prime}$-bipyridine $(0.47 \mathrm{~g}, 3 \mathrm{mmol})$, p-toluenesulfonic acid $(0.34 \mathrm{~g}, 2 \mathrm{mmol})$, and 1,4-naphthoquinone $(3.1 \mathrm{~g}, 20 \mathrm{mmol})$ in $30 \mathrm{ml} \mathrm{CH} \mathrm{CH}_{3} \mathrm{OH}$ were added styrene $(48 \mathrm{ml}, 0.4 \mathrm{~mol})$ and norbornene $(9.42 \mathrm{~g}, 0.1 \mathrm{~mol})$. The mixture was placed in a $250 \mathrm{ml}$ Parr bomb and charged with $2.8 \mathrm{MPa}$ of $\mathrm{CO}$ under argon atmosphere. After stirring at $90^{\circ} \mathrm{C}$ for $2 \mathrm{~h}$, a polymer precipitate $(8.2 \mathrm{~g})$ was obtained by adding methanol to the reaction mixture. The polymer product was washed with methanol and dried under vacuum. The polymer did not melt below $143^{\circ} \mathrm{C}$. Osmometric measurements showed the NBE/St/ $\mathrm{CO}$ terpolymer to have a number-average molecular weight $\left(\bar{M}_{n}\right)$ ca. 3900 . 
The above procedure was used in other reactions where the initial moles of norbornene were varied.

\section{Measurements}

TGA experiments were performed with a Perkin-Elmer thermal mechanical analyser Model TGS-II system. The glass-transition temperature $\left(T_{\mathrm{g}}\right)$ was measured with a $\mathrm{Du}$ Pont 9000 differential scanning calorimeter at a heating rate of $10^{\circ} \mathrm{Cmin}^{-1}$. Molecular weight was determined by gel permeation chromatography (GPC).

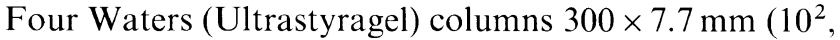
$10^{3}, 10^{4}, 10^{5}$ in a series) were used for GPC analysis with THF $\left(1 \mathrm{ml} \mathrm{min}{ }^{-1}\right)$ as the eluent. The eluents were monitored with a UV detector (Gilson model 116) using a $254 \mathrm{~nm}$. Polystyrene was used as the standard. Number-average molecular weight was determined by a vapor pressure osmometer (Knauer model 1100) in pyridine at $65^{\circ} \mathrm{C}$. IR spectra were recorded using Bio-Rad FTS-40 (FTIR). ${ }^{1} \mathrm{H}$ and ${ }^{13} \mathrm{C}$ NMR (carbon frequency $100.40 \mathrm{MHz}$ ) spectra were recorded with a JEOL EX-400 spectrometer from $13 \mathrm{~g} / 100 \mathrm{~cm}^{3}$ polymer solution in $\mathrm{CDCl}_{3}$ at $30^{\circ} \mathrm{C}$. Tetramethylsilane (TMS) was the internal standard. Partial resonance assignment was completed by Distortionless Enhancement following Polarization Transfer (DEPT) spectral acquisition procedures. An X-ray diffractometer was recorded using the powder method (Philips X-ray diffractometer, model PW 1710).

\section{RESULTS AND DISCUSSION}

\section{Terpolymerization of $\mathrm{CO}$ with Styrene and $\mathrm{NBE}$}

The terpolymerization of styrene, norbornene, and carbon monoxide with catalyst palladium acetate in $\mathrm{CH}_{3} \mathrm{OH}$ at $90^{\circ} \mathrm{C}$ was carried out. Table I summarizes the results at various molar ratios of norbornene to styrene. According to the table, increasing the molar ratio of norbornene to styrene resulted in enhanced of molecular weight and yield of the terpolymer. Number-average molecular weights $\left(\bar{M}_{n}\right)$ of the terpolymers measured by GPC ranged from $3000-5000$ and generally corresponded to those measured by VPO. This is consistent with the measured molar ratio of NBE/St from measurement of ${ }^{1} \mathrm{H}$ NMR spectra (see Table I) in terpolymers. That is, norbornene was found to be more reactive than styrene when copolymerized with carbon monoxide. Sen et al. ${ }^{19,20}$ has proposed that, in most olefins, the observed product that has reacted with carbon monoxide is a vinyl ketone formed through a $\beta$-hydrogen abstraction step. ${ }^{19-21}$ However, in the case of norbornene, because of steric inaccessibility of the available $\beta$-hydrogen atoms, stable organometallic derivatives could be isolated. ${ }^{19}$ Thus, it could be easily polymerized with $\mathrm{CO}$. Results obtained from the terpolymer structure are basis for as formula (1).

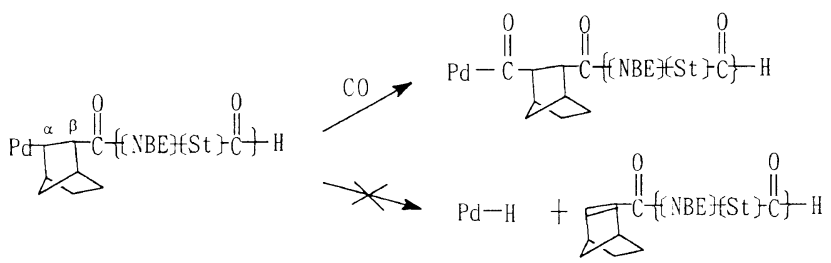

The infrared spectra of all the terpolymers in Table I include two features at 1725 and $1690 \mathrm{~cm}^{-1}$ that are attributed to carbonyl groups in ketones (repeating unit) and ester (end group), respectively. As described previously, ${ }^{7,22-24}$ the formation of polyketoester is considered to result from terpolymerization of the polymer end with $\mathrm{CH}_{3} \mathrm{OH}$ as solvent.

Figure 1 shows TG thermograms of the terpolymers. Table II presents temperatures corresponding to initial

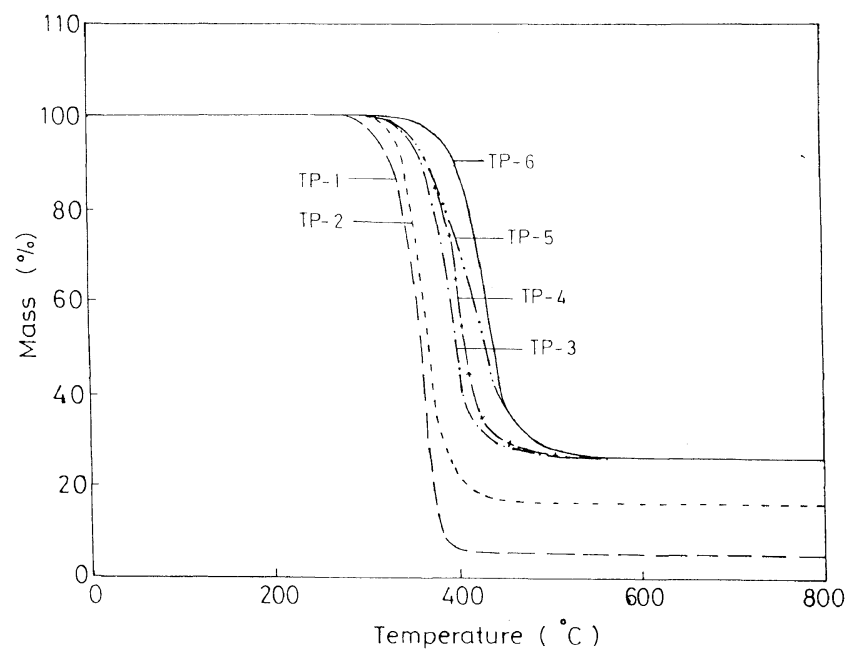

Figure 1. TGA curves of $\mathrm{NBE} / \mathrm{St} / \mathrm{CO}$ terpolymers in nitrogen (heating rate, $10^{\circ} \mathrm{C} \mathrm{min}^{-1}$ ): a) terpolymerization conditions: styrene $(0.4 \mathrm{~mol}) ; \mathrm{CH}_{3} \mathrm{OH}(30 \mathrm{ml}) ; \mathrm{Pd}\left(\mathrm{CH}_{3} \mathrm{COO}\right)_{2}(0.1 \mathrm{mmol}) ; 2,2^{\prime}$-bipyridine $(3 \mathrm{mmol}) ; 1,4$-naphthoquinone $(20 \mathrm{mmol}) ; p$-toluenesulfonic acid $(2$ $\mathrm{mmol}$ ); temperature, $90^{\circ} \mathrm{C}$; partial pressure of $\mathrm{CO}, \mathrm{P}(\mathrm{CO})=2.8 \mathrm{MPa}$; reaction period, $2 \mathrm{~h}$. b) TP-1, _- —; TP-2, ---; TP-3, —._.-; TP-4, - +- - - TP-5, —..... TP-6, -

Table I. Terpolymerization of $\mathrm{CO}$ with styrene and norbornene ${ }^{\mathrm{a}}$

\begin{tabular}{|c|c|c|c|c|c|c|c|}
\hline $\begin{array}{l}\text { Polymer } \\
\text { code }\end{array}$ & $\begin{array}{l}\mathrm{NBE} / \mathrm{St} \\
\text { molar ratio }\end{array}$ & $\frac{\text { Yield }}{\mathrm{g}}$ & $\frac{\text { Productivity }}{\text { g polymer } \mathrm{g}^{-1} \mathrm{Pd} \mathrm{h}^{-1}}$ & $\begin{array}{c}\bar{M}_{n}{ }^{\mathrm{b}} \\
(\mathrm{GPC})\end{array}$ & $\begin{array}{c}\bar{M}_{n}^{\mathrm{c}} \\
(\mathrm{VPO})\end{array}$ & $\frac{v_{\mathrm{C}=\mathrm{O}}}{\mathrm{cm}^{-1}}$ & $\begin{array}{c}\text { NBE } / \mathrm{St} \\
\text { molar ratio }^{\mathrm{d}}\end{array}$ \\
\hline TP-1 & 0 & 6.25 & 294 & - & - & 1750,1698 & $-^{\mathrm{e}}$ \\
\hline TP-2 & 0.25 & 8.17 & 384 & 2960 & 3900 & 1725,1690 & $-^{\mathrm{e}}$ \\
\hline TP-3 & 0.375 & 10.36 & 487 & 3320 & 4400 & 1725,1690 & 0.57 \\
\hline TP-4 & 0.50 & 15.63 & 735 & 4040 & 4600 & 1725,1690 & 1.41 \\
\hline TP-5 & 0.75 & 18.44 & 867 & 4430 & 4800 & 1725,1690 & 2.16 \\
\hline TP-6 & 1.00 & 20.70 & 973 & 4770 & 4900 & 1725,1690 & 2.80 \\
\hline
\end{tabular}

${ }^{a}$ Experimental conditions: styrene $(0.4 \mathrm{~mol}) ; \mathrm{CH}_{3} \mathrm{OH}(30 \mathrm{ml}) ; \mathrm{Pd}\left(\mathrm{CH}_{3} \mathrm{COO}\right)_{2}(0.1 \mathrm{mmol}) ; 2,2$-bipyridine (3 mmol); 1,4-naphthoquinone $(20 \mathrm{mmol}) ; p$-toluenesulfonic acid $(2 \mathrm{mmol})$; temperature, $90^{\circ} \mathrm{C}$; partial pressure of $\mathrm{CO}, \mathrm{P}(\mathrm{CO})=2.8 \mathrm{MPa}$; reaction period, $2 \mathrm{~h}$. ${ }^{\mathrm{b}} \mathrm{Number}$-average molecular weight determined by GPC (polystyrene standards). ${ }^{\circ}$ Number-average molecular weight determined by VPO in pyridine at $65^{\circ} \mathrm{C} .{ }^{d} \mathrm{Molar}$ ratio of NBE/St was calculated from ${ }^{1} \mathrm{H}$ NMR spectra; $\mathrm{CDCl}_{3}$ was used as solvent. ${ }^{\mathrm{c}}$ Polymer was insoluble in $\mathrm{CDCl}_{3}$. 
Table II. Thermal properties of the terpolymer ${ }^{\mathrm{a}}$

\begin{tabular}{|c|c|c|c|c|c|c|}
\hline \multirow{2}{*}{$\begin{array}{l}\text { Polymer } \\
\text { code }\end{array}$} & \multirow{2}{*}{$\begin{array}{l}\mathrm{NBE} / \mathrm{St} \\
\text { molar ratio }\end{array}$} & $T_{\mathrm{g}}^{\mathrm{b}}$ & $T_{\mathrm{d}}^{\mathrm{ic}}$ & $T_{\mathrm{d}}^{50 \% \mathrm{~d}}$ & $T_{\mathrm{d}}^{\max \mathrm{e}}$ & Char yield at $500^{\circ} \mathrm{C}$ \\
\hline & & ${ }^{\circ} \mathrm{C}$ & ${ }^{\circ} \mathrm{C}$ & ${ }^{\circ} \mathrm{C}$ & ${ }^{\circ} \mathrm{C}$ & $\%$ \\
\hline TP-1 & 0 & 67 & 306 & 363 & 366 & 5 \\
\hline TP-2 & 0.25 & 90 & 326 & 371 & 368 & 17 \\
\hline TP-3 & 0.375 & 102 & 327 & 401 & 398 & 26 \\
\hline TP-4 & 0.50 & 116 & 328 & 411 & 409 & 26 \\
\hline TP-5 & 0.75 & 120 & 329 & 426 & 423 & 26 \\
\hline TP-6 & 1.00 & 143 & 377 & 433 & 430 & 26 \\
\hline
\end{tabular}

${ }^{a}$ Experimental conditions: styrene $(0.4 \mathrm{~mol}) ; \mathrm{CH}_{3} \mathrm{OH}(30 \mathrm{ml}) ; \mathrm{Pd}\left(\mathrm{CH}_{3} \mathrm{COO}\right)_{2}(0.1 \mathrm{mmol}) ; 2,2^{\prime}$-bipyridine (3 mmol); 1,4-naphthoquinone $(20 \mathrm{mmol}) ; p$-toluenesulfonic acid $(2 \mathrm{mmol})$; temperature, $90^{\circ} \mathrm{C}$; partial pressure of $\mathrm{CO}, \mathrm{P}(\mathrm{CO})=2.8 \mathrm{MPa}$; reaction period, $2 \mathrm{~h} .{ }^{\mathrm{b}} \mathrm{DSC}$ analysis conducted at a heating rate of $10^{\circ} \mathrm{C} \mathrm{min}{ }^{-1}$. ${ }^{\mathrm{c}}$ Thermogravimetric analysis conducted at a heating rate of $10^{\circ} \mathrm{C} \min ^{-1}$ in nitrogen. ${ }^{\mathrm{d}} T_{\mathrm{d}}{ }^{50} \%$ is the temperature at which $50 \%$ loss of mass was observed. ${ }^{\mathrm{e}} T_{\mathrm{d}}{ }^{\max }$ is the temperature at which maximal loss of mass was observed.

mass loss $\left(T_{\mathrm{d}}^{\mathrm{i}}\right), 50 \%$ mass loss $\left(T_{\mathrm{d}}{ }^{50 \%}\right)$, inception of fast degradation $\left(T_{\mathrm{d}}^{\max }\right)$ and char yield remaining at $500^{\circ} \mathrm{C}$. All the polymers remains stable up to $300^{\circ} \mathrm{C}$ and start degrading between $306^{\circ} \mathrm{C}$ and $377^{\circ} \mathrm{C}$. The experimental results indicate that increasing the molar ratio of norbornene to styrene is more thermally stable than $\mathrm{St} / \mathrm{CO}$ copolymer. That is, polymer chains with more ring structures of norbornene should provide a greater thermal stability. As the concentration of norbornene increases, $T_{\mathrm{g}}$ also increases due to the bulkiness of the ring structure unit of norbornene which hinders polymer chain movement.

\section{$X$-Ray Diffractogram of Terpolymer}

$X$-Ray diffractograms of various terpolymers appear in Figure 2 as intensity vs. $2 \theta$, where $\theta$ is the angle of diffraction (Bragg angle). Table III presents the crystallinities of various terpolymers. From Figure 2 and Table III, the degree of crystallinity decreases with increase in the molar ratio of norbornene to styrene. A previous work ${ }^{25}$ indicated that the $\mathrm{St} / \mathrm{CO}$ copolymer has a syndiotactic structure. However, under the same experimental conditions, with increasing norbornene content, the styrene/CO units became increasingly isolated, thereby resulting in loss of tactic styrene/CO blocks and, ultimately, decreased crystallinity of terpolymer. ${ }^{26}$ The angle of maximum intensity of X-ray diffraction of terpolymers was altered from $23.9^{\circ}$ to $17.6^{\circ}$. This may be accounted for by the bulky norbornene group, which increases the distance between polymer chains. ${ }^{27,28}$

The solubility of the terpolymer depends on the molar ratio of norbornene to styrene in the terpolymers. For instance, the copolymer of carbon monoxide with styrene is insoluble in common organic solvents such as chloroform, THF, and methylene chloride. ${ }^{26}$ Terpolymers introducing a norbornene content larger than 0.375 molar ratio to styrene would cause them to be soluble in chloroform, THF, methylene chloride, ethyl acetate, benzene, dimethylacetamide, and pyridine. Solubility generally increases with decreasing crystallinity. ${ }^{29}$

Characterization of NBE/St/CO Terpolymer by IR, ${ }^{1} \mathrm{H}$ $N M R$, and ${ }^{13} C N M R$

The terpolymer of NBE, styrene, and CO was characterized by IR, ${ }^{1} \mathrm{H}$ NMR, and ${ }^{13} \mathrm{C}$ NMR spectroscopy. Strong IR absorption about $1690 \mathrm{~cm}^{-1}$ is ascribed to

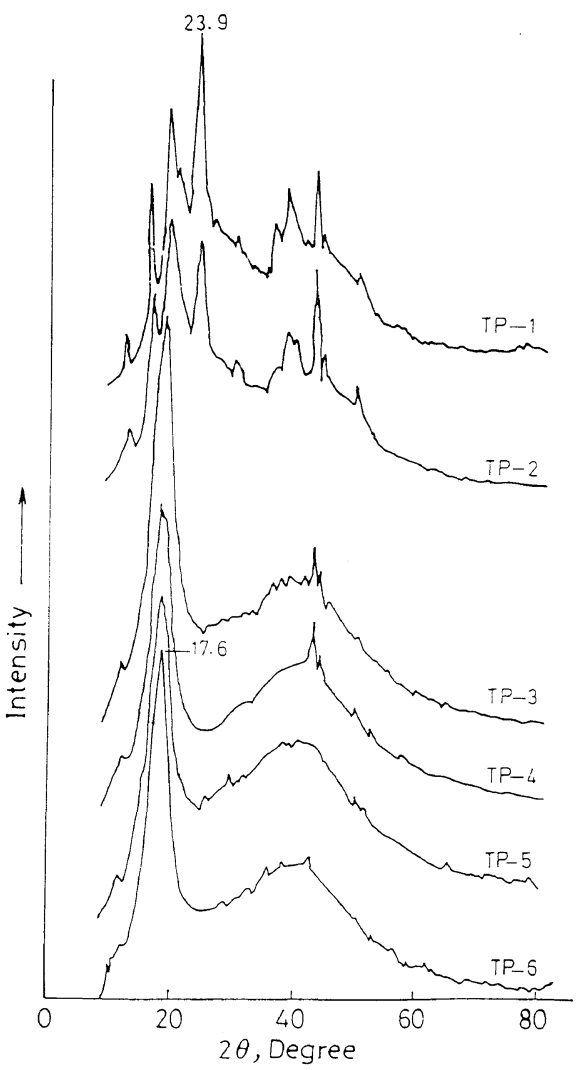

Figure 2. X-Ray diffractograms of $\mathrm{NBE} / \mathrm{St} / \mathrm{CO}$ terpolymers: Terpolymerization conditions: styrene $(0.4 \mathrm{~mol}) ; \mathrm{CH}_{3} \mathrm{OH}(30 \mathrm{ml})$; $\mathrm{Pd}\left(\mathrm{CH}_{3} \mathrm{COO}\right)_{2}(0.1 \mathrm{mmol}) ; 2,2^{\prime}$-bipyridine $(3 \mathrm{mmol}) ; 1,4$-naphthoquinone $(20 \mathrm{mmol}) ; p$-toluenesulfonic acid $(2 \mathrm{mmol})$; temperature, $90^{\circ} \mathrm{C}$; partial pressure of $\mathrm{CO}, \mathrm{P}(\mathrm{CO})=2.8 \mathrm{MPa}$; reaction period, $2 \mathrm{~h}$.

Table III. Crystallinity of the terpolymer

\begin{tabular}{ccc}
\hline \multirow{2}{*}{ Polymer code } & $\begin{array}{c}\text { NBE/St } \\
\text { molar ratio }\end{array}$ & Crystallinity \\
\cline { 3 - 3 } & 0 & $\%$ \\
\hline TP-1 & 0.25 & 50.1 \\
TP-2 & 0.375 & 45.5 \\
TP-3 & 0.50 & 39.2 \\
TP-4 & 0.75 & 38.8 \\
TP-5 & 1.00 & 37.0 \\
TP-6 & & 36.7 \\
\hline
\end{tabular}

${ }^{\mathrm{a}}$ Experimental connditions: styrene $(0.4 \mathrm{~mol}) ; \mathrm{CH}_{3} \mathrm{OH}(30 \mathrm{ml})$; $\mathrm{Pd}\left(\mathrm{CH}_{3} \mathrm{COO}\right)_{2}(0.1 \mathrm{mmol}) ; 2,2^{\prime}$-bipyridine $(3 \mathrm{mmol})$; 1,4-naphthoquinone $(20 \mathrm{mmol}) ; p$-toluenesulfonic acid $(2 \mathrm{mmol})$; temperature, $90^{\circ} \mathrm{C}$; partial pressure of $\mathrm{CO}, \mathrm{P}(\mathrm{CO})=2.8 \mathrm{MPa}$; reaction period, $2 \mathrm{~h}$. 
the carbonyl group (Table I, TP-4). The absorption at $1294 \mathrm{~cm}^{-1}$ indicates an intact methylene bridge of the NBE group. Absorptions at $3100-3000 \mathrm{~cm}^{-1}$ and 3000 $2800 \mathrm{~cm}^{-1}$ are ascribed to aromatic $\mathrm{C}-\mathrm{H}$ stretching and aliphatic $\mathrm{C}-\mathrm{H}$ stretching of the styrene and norbornene groups, respectively. Aliphatic $\mathrm{C}-\mathrm{H}$ deformation and aromatic $\mathrm{C}-\mathrm{C}$ stretching absorption are localed at $1500-1430 \mathrm{~cm}^{-1}$. Absorptions at 870, 750, and 700 $\mathrm{cm}^{-1}$ are ascribed to aromatic $\mathrm{C}-\mathrm{H}$ deformation. According to Figure 3 , the ${ }^{1} \mathrm{H}$ NMR spectrum $\left(\mathrm{CDCl}_{3}\right)$ of the terpolymer shows broad absorption at $0.6-3.8$ $\mathrm{ppm}$. Absorption at $0.60-3.8 \mathrm{ppm}$ is to the ring structure of norbornene $\mathrm{e}^{23,30}$ overlapping with the styrene group. Absorption at $6.55-7.15 \mathrm{ppm}$ is due to the styrene group. The alternating $\mathrm{St} / \mathrm{CO}$ copolymer prepared according to ref 25 was syndiotactic, and thus with increasing norbornene content, the styrene/ $\mathrm{CO}$ units became increasingly isolated, thereby resulting in loss of the tactic styrene/CO blocks. Ultimately, a broad ${ }^{1} \mathrm{H}$ NMR spec-

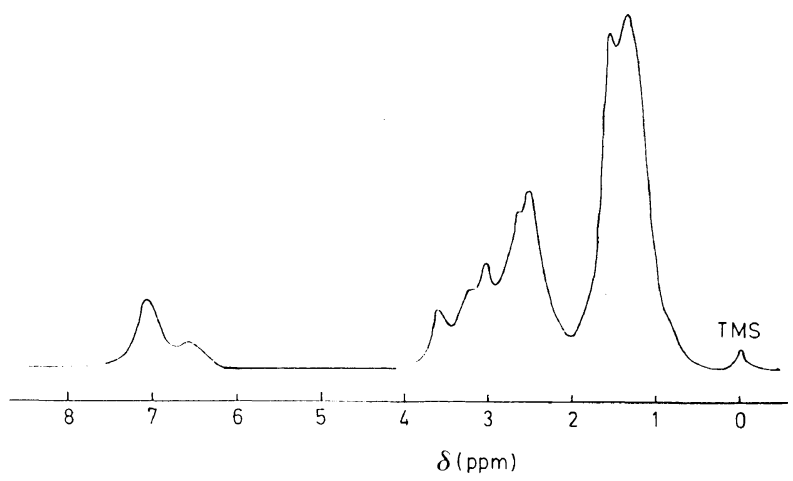

Figure 3. ${ }^{1} \mathrm{H}$ NMR spectrum of $\mathrm{NBE} / \mathrm{St} / \mathrm{CO}$ terpolymer: Solvent, $\mathrm{CDCl}_{3}$. Terpolymerization conditions: styrene $(0.4 \mathrm{~mol})$; norbornene $(0.2 \mathrm{~mol}) ; \mathrm{CH}_{3} \mathrm{OH}(30 \mathrm{ml}) ; \mathrm{Pd}\left(\mathrm{CH}_{3} \mathrm{COO}\right)_{2}(0.1 \mathrm{~mol}) ; 2,2^{\prime}$-bipyridine $(3 \mathrm{mmol}) ; 1,4$-naphthoquinone $(20 \mathrm{mmol}) ; p$-toluenesulfonic acid $(2$ $\mathrm{mmol}$ ); temperature, $90^{\circ} \mathrm{C}$; partial pressure of $\mathrm{CO}, \mathrm{P}(\mathrm{CO})=2.8 \mathrm{MPa}$; reaction period, $2 \mathrm{~h}$. trum was obtained. ${ }^{26}$

Figure 4 shows the ${ }^{13} \mathrm{C}$ NMR spectrum of the NBE/ $\mathrm{St} / \mathrm{CO}$ terpolymer. The signal at $208 \mathrm{ppm}$ is attributed to the carbonyl carbon. The line at $173 \mathrm{ppm}$ is due to the ester group $\left(\mathrm{CH}_{3}-\mathrm{O}-(\mathrm{C}=\mathrm{O})-\right)$ at the end of the terpolymer chain. In this figure, the peaks in the DEPT (distortionless enhancement by polarization transfer) spectrum are also shown. Signals at $20-55 \mathrm{ppm}$ support that the terpolymer contains ring structures. Signals around $28 \mathrm{ppm}$, as expected for the C-5 and C-6 of exo-substituted bicycloheptanes, are present. Signals appearing at higher field $c a .22 \mathrm{ppm}$ which correspond to endo carbons are also present. ${ }^{31}$ Their presence implies that norbornene- $\mathrm{CO}$ sequences not only have cis, exo stereochemistry, but also endo stereochemistry. ${ }^{31-35}$ Signals appearing at 145, 126, 125.5, 123.5, 53.3, and $42.3 \mathrm{ppm}$ are due to styrene groups. This further confirms that $\mathrm{CO}$ is definitely polymerized with norbornene and styrene.

\section{Hydrogenation}

Because the carbonyl group can be easily modified chemically, polyketones are expected to be excellent starting materials for synthesizing functional polymers which react with curing agents to yield thermoset resins. Hydrogenation of polyketones with a reduction agent (lithium aluminum hydride, $\mathrm{LiAlH}_{4}$ ) in THF at $65^{\circ} \mathrm{C}$ yielded hydroxyl-containing polymer represented as in (eq 2) and Figure 5. The hydrogenated polymer was

$$
\underset{\left.+(\mathrm{St}-\mathrm{NBE}-\mathrm{C})_{\mathrm{n}}\right)}{\mathrm{LiAlH}_{4}} \underset{\text { in THF }}{\longrightarrow}+\left(\mathrm{St}-\mathrm{NBE}-\underset{\mathrm{H}}{\left.\stackrel{\mathrm{OH}}{\mathrm{n}_{n}}\right\}}\right.
$$

completely soluble in chloroform, methylene chloride, ethyl acetate, THF, dimethylacetamide, pyridine, and benzene, and partially soluble in dimethylsulfoxide,
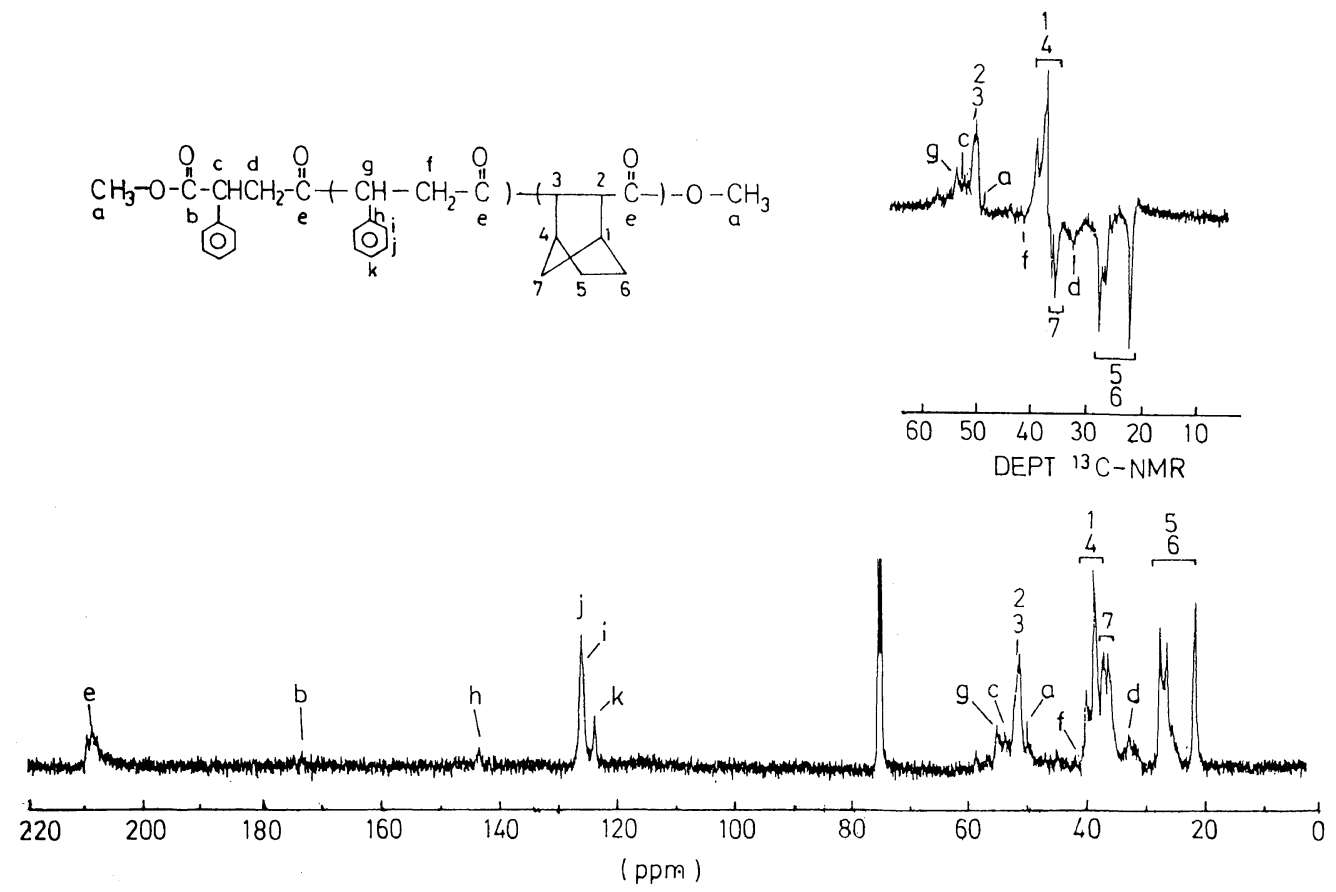

Figure 4. ${ }^{13} \mathrm{C}$ NMR and DEPT spectra of the $\mathrm{NBE} / \mathrm{St} / \mathrm{CO}$ terpolymer. Solvent, $\mathrm{CDCl}_{3}$. Terpolymerization conditions: styrene (0.4 mol); norbornene $(0.2 \mathrm{~mol}) ; \mathrm{CH}_{3} \mathrm{OH}(30 \mathrm{ml}) ; \mathrm{Pd}\left(\mathrm{CH}_{3} \mathrm{COO}\right)_{2}(0.1 \mathrm{mmol}) ; 2,2^{\prime}$-bipyridine $(3 \mathrm{mmol}) ; 1,4$-naphthoquinone $(20 \mathrm{mmol}) ; p$-toluenesulfonic acid $(2 \mathrm{mmol})$; temperature, $90^{\circ} \mathrm{C}$; partial pressure of $\mathrm{CO}, \mathrm{P}(\mathrm{CO})=2.8 \mathrm{MPa}$; reaction period, $2 \mathrm{~h}$. 


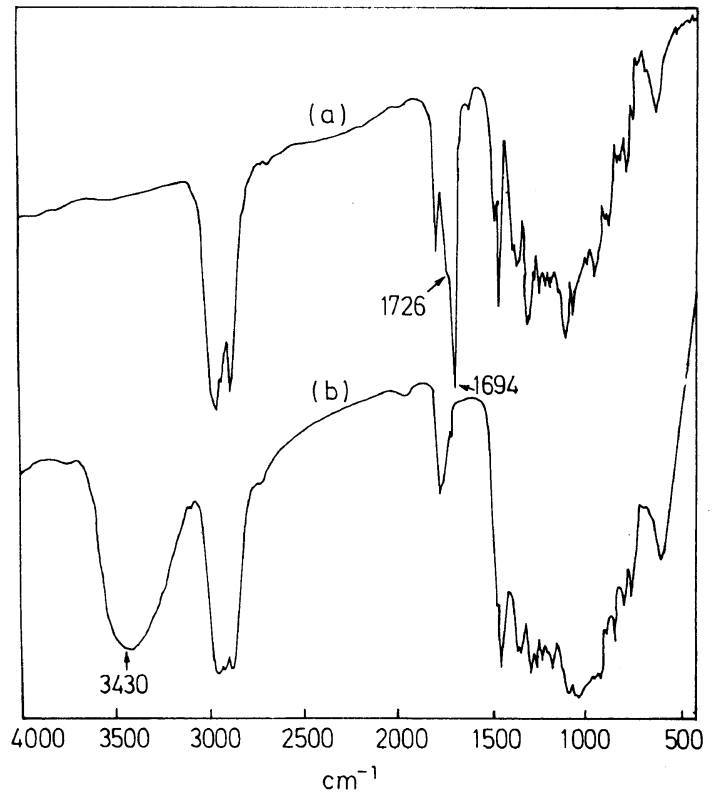

Figure 5. IR spectra of hydrogenated polyketones with a reducing agent (lithium aluminum hydride, $\mathrm{LiAlH}_{4}$ ) in $\mathrm{THF}$ at $65^{\circ} \mathrm{C}$. (a) before; (b) after hydrogenation.

acetone, and insoluble in $n$-hexane and methanol. The absence of infrared absorption corresponding to the carbonyl group $\left[1694 \mathrm{~cm}^{-1}\right.$, Figure 5(a)] and specific absorption of $v_{\mathrm{OH}}$ at $3430 \mathrm{~cm}^{-1}$ [Figure 5(b)] indicate the essentially complete conversion of ketone functional groups to alcohol groups without cleavage of the polyketone chain. According to the ${ }^{13} \mathrm{C}$ NMR spectrum, the appearance of the signal due to the methine group at $68 \mathrm{ppm}$ and disappearance of the signal due to the carbonyl group at $208 \mathrm{ppm}$ after hydrogenation confirm the complete hydrogenation of the polyketone.

Acknowledgment. The authors should like to thank the National Science Council of the Republic of China for financial support.

\section{REFERENCES}

1. A. Sen, Adv. Polym. Sci., 73/74, 125 (1986).
2. M. Heskin and J. E. Guillet, Macromolecules, 3, 224 (1970).

3. G. H. Hartley and J. E. Guillet, Macromolecules, 1, 413 (1968).

4. G. H. Hartley and J. E. Guillet, Macromolecules, 1, 165 (1968).

5. M. M. Brubaker, D. D. Coffman, and H. H. Hoehn, J. Am Chem. Soc., 74, 1509 (1952).

6. Y. Morishima, T. Tadizawa, and S. Murahashi, Eur. Polym. J., 9, 669 (1973).

7. E. Drent, J. A. M. Van Broekhoven, and M. J. Doyle, J. Organomet. Chem., 417, 235 (1991).

8. E. Drent, Eur. Patent, Appl. EP 229408 (1987).

9. J. Van Broekhoven, Eur. Patent Appl. EP 361584 (1989).

10. P. K. Wong, J. J. Reijsper, and A. W. Vander Made, Eur. Patent Appl. EP 408155 (1990).

11. W. P. Gergen, U.S. Patent 4900789 (1990).

12. W. P. Gergen and R. G. Lutz, U.S. Patent 4904744 (1990).

13. E. Drent and R. L. Wife, U.S. Patent 4970294 (1990).

14. P. K. Wong, Eur. Patent Appl. EP 384517 (1990).

15. P. K. Wong, Eur. Patent Appl. EP 404228 (1990).

16. R. Strenk, "Olefin Metathesis and Polymerization Catalysts," Y. Imamoglu, B. Z. Karan, and A. J. Amass, Ed., Kluwer, The Netherlands, 1990, p 472.

17. Anon, Plastic Focus, 14, 3 (1982).

18. A. A. Smaardijk and A. H. Kramer, Eur. Patent Appl. EP. 372602 (1989).

19. A. Sen, Acc. Chem. Res., 26, 303 (1993).

20. J. S. Brumhaugh, R. R. Whittle, M. A. Parvez, and A. Sen, Organometallics, 9, 1735 (1990).

21. F. Ozawa, T. Hayashi, H. Koide, and A. Yamamoto, J. Chem. Soc., Chem. Commun., 1469 (1991).

22. D. J. Liaw, J. Polym. Sci., Polym. Chem. Ed., 31, 309 (1993).

23. D. J. Liaw and B. F. Lay, Polym. J., 28, 266 (1996).

24. T. W. Lai and A. Sen, Organometallics, 3, 866 (1984).

25. B. Vincezo, C. Paoio, L. Laura, and M. Trifuoggi, Makromol. Chem., Rapid Commun., 14, 261 (1993).

26. A. Sen and Z. Jiang, Macromolecules, 26, 911 (1993).

27. D. J. Liaw and S. P. Lin, J. Appl. Polym. Sci., in press.

28. D. J. Liaw and S. P. Lin, Eur. Polym. J., in press.

29. D. J. Liaw, J. Polym. Sci., Polym. Chem. Ed., 33, 605 (1995).

30. F. Hojabri, M. M. Mohaddes and A. Talab, Polymer, 17, 710 (1976).

31. D. Roberto, M. Catellani, and G. P. Chiusoli, Tetrahedron Lett., 29, 2115 (1988)

32. J. B. Stothers, "Carbon-13 NMR Spectroscopy," Academic Press, New York, N.Y., 1972, p 178.

33. D. E. James and J. K. Stille, J. Org. Chem., 41, 1504 (1976).

34. E. Lippmaa, T. Pehk, N. A. Belikova, A. A. Bobyleva, A. N. Bobyleva, A. N. Kalinichenko, M. D. Ordubadi, and A. F. Plate, Org. Magn. Res., 8, 74 (1976).

35. K. Laihia, J. Paasvirta, H. Pikkarainen, and S. Aho-Pulliainen, Org. Magn. Res., 72, 117 (1984). 